\title{
The accuracy of measurements in a time study of harvester operations
}

\author{
Grzegorz Szewczyk ${ }^{*}$ (iD) and Janusz M. Sowa
}

\begin{abstract}
Background: Work time measurements are the starting point for any calculation of unit costs of machine exploitation; therefore, the accuracy of evaluating these costs determines the economic effectiveness of technological solutions employed in forest work. The research aimed to determine the level of measurement error of harvester operation times by means of a chronometric method.

Methods: Different methods for measuring the components of the work cycle in cut-to-length harvesting operations were compared. These operations consisted of a thinning and a clear-cut harvesting operation in two Scots pine (Pinus sylvestris L.) stands in central Poland. The average duration of a work cycle was determined from cumulative timing using either the on-board PSION microcomputers or analysis of video footage. Results from these two methods were compared with the standard method used in work study which is snap-back timing (i.e. the timer is reset at the end of each activity within the work cycle, the average time for each activity calculated and then summed to give the average cycle time) using the PSION microcomputer.

Results: The average duration of the work cycles estimated from cumulative timing of video footage were 55.0 and $52.3 \mathrm{~s}$ for the thinning and clear-cut operations, respectively. The cumulative timing method using the PSION on-board computer underestimated these cycle times by ca. $14 \%$ in thinning operations and by $22 \%$ in clear-cut operations. The snap-back timing method, which measures the duration of certain operations separately, underestimated the average work cycle time in the clear-cut operation by $6 \%$ but overestimated it by ca. $12 \%$ in the thinning operation. In both operations, most of the difference in work cycle time estimates were due to differences in the time recorded for delimbing and bucking activities.
\end{abstract}

Conclusions: The accuracy of work time measurement taken using the standard methods — snap-back timing - depends on the variability of work cycles. The hitherto employed method of snap-back timing is more accurate than the cumulative timing method with respect to both stable and more changeable work cycles.

Keywords: Time study, Harvester, Timber harvesting

\section{Background}

Studies of work time are one of the basic analyses for optimising production processes. The objectives of such investigations include optimisation of planning processes, stimulation of remuneration systems, optimisation of employment and implementation of standards for machine utilisation (Kanawaty 1992). In forestry, one of the goals of work time studies is to improve the efficiency of timber-harvesting operations (Stampfer and Lexer 2003; Kangas et al. 2002; Szewczyk 2009;

\footnotetext{
*Correspondence: rlszewcz@cyf-kr.edu.pl

Institute of Forest Utilization and Forest Technology, Department of Forest and Wood Utilization, University of Agriculture in Krakow, al. 29 Listopada 46, 31-425 Kraków, Poland
}

Skoupý 2011). A key advancement in the field of work time research was the division of a work process into its basic elements, such as operations, treatments, activities and movements. This approach was proposed by F.W. Taylor at the beginning of the twentieth century and has been commonly employed in work-related investigations ever since (Sajkiewicz 1981; Palmroth 2011). Thus, the analysis of work time is based on distinguishing particular work cycles, i.e. recurrent work phases, and then measuring them using the chronometric method (time study) (Samset 1990; Kanawaty 1992). A time study is the most common manner of measuring work time at worksites in forestry. Accurate 
measurements of work times are particularly important in complex, variable production processes, which are typical of timber harvesting and extraction (Palmroth 2011; Szewczyk 2011a; Szewczyk and Stańczykiewicz 2012; Szewczyk et al. 2014).

Conducting a time study of modern timber-harvesting processes with the use of harvesters is difficult due to the fact that harvester work cycles are both short and very changeable. In work study research, time studies are conducted using microcomputers, on-board computer systems and digital video footage. For more than a decade, microcomputers equipped with time study software have been employed in these analyses (Sowa and Szewczyk 2013; Szewczyk 2014b; Eliasson et al. 2015). Time logs generated by the computer systems used to operate machinery may also be used to determine time used in their operation (Purfürst and Erler 2011). The most precise, but also the most time-consuming, method of time study is to collect digital video footage and then analyse this to determine specific work times (Walczyk et al. 2009; Smidt and McDaniel 2012; Borz et al. 2015). Microcomputer-generated measurements are much more accurate than comparable measurements taken using stopwatches, but accuracy is still limited due to a certain delay in the human response to observed phenomena and difficulty in distinguishing terminal points between particular activities. Defining the types and magnitude of such errors would make work time standards based on such simple calculation methods more objective. This would also facilitate a comparison of results across studies that have used different measurement methods.

The present research aims to compare the work cycle times for harvester operations measured using on-board microcomputers with those obtained from detailed video analysis. The analyses cover the duration of work cycles for a harvester performing thinning and clear-cutting operations in two Scots pine (Pinus sylvestris L.) stands located in south-western Poland.

\section{Methods}

Site details

The field research was carried out in Gidle Forest District, managed by the Regional Directorate of the State Forests in Katowice in south-western Poland. Two stands were selected for this study. Both were dominated by Scots pine and ranged in age from 86 up to 121 years.
The species composition and the quality of timber harvested in those stands were consistent with the habitat type (Table 1 ).

In the stands chosen for these studies, typical silvicultural treatments were performed, such as late (low) thinning and clear-cutting. In thinned stands, sanitation cuts were done, trees of low value were removed and preparatory cuts were executed for the purpose of preparation of the forest site for natural regeneration. As a result of these treatments, an increase in tree diameter growth was obtained by ensuring better crown light exposure for the most valuable trees, consequently improving the quality of harvested wood. The trees designated for felling were identified by employees of the State Forests, according to the Rules of Silviculture currently valid in Poland. These trees were marked with a dot of fluorescent paint at a height of ca. $170 \mathrm{~cm}$. The dots were painted on the side of a tree stem facing the skid trails along which the harvester moved. With regard to clear-cut stands, tasks included all of the trees growing there, preceded by the removal of undergrowth in order to ensure appropriate visibility of tree stems. The boundaries of felling sites were permanently marked in the field with the use of horizontal lines painted on stems of the first trees that were excluded from harvesting.

The stands and the manner of harvesting performance corresponded with the standards accepted in the European forest management; thus, the results obtained in these studies are believed to have revealed average work conditions in Scots pine stands within the middle and older age classes.

The timber was harvested in both stands by means of the Ponsse ERGO harvester using the cut-to-length (CTL) system, where the entire wood-processing operation is performed directly after the tree has been felled (Dvořák et al. 2011). The felled trees were processed into the following assortment of sections: long wood with a length ranging from 8 to $12 \mathrm{~m}$; logs with a length of $4 \mathrm{~m}$; and middle-sized timber with a length of $2.5 \mathrm{~m}$. The harvester operator had completed specialised training courses in operating multi-purpose machines and had 3 years' experience.

Four working shifts were analysed, two for each cutting category (i.e. thinning or clear-cutting). The measurements were taken continuously over a period of over $500 \mathrm{~min}$.

Table 1 Selected features of the investigated stands

\begin{tabular}{|c|c|c|c|c|c|c|}
\hline $\begin{array}{l}\text { Harvesting } \\
\text { operation }\end{array}$ & $\begin{array}{l}\text { Age } \\
\text { (years) }\end{array}$ & $\begin{array}{l}\text { Stand density index ( } \mathrm{m}^{3} \text { ha }{ }^{-1} \text { in the } \\
\text { stand } / \mathrm{m}^{3} \mathrm{ha}^{-1} \text { acc. to estimation tables) }\end{array}$ & $\begin{array}{l}\text { Diameter at breast } \\
\text { height }(\mathrm{cm})\end{array}$ & Height (m) & $\begin{array}{l}\text { Large timber } \\
\text { volume }\left(\mathrm{m}^{3} \mathrm{ha}^{-1}\right)\end{array}$ & $\begin{array}{l}\text { Timber harvest } \\
\left(\mathrm{m}^{3} \mathrm{ha}^{-1}\right)\end{array}$ \\
\hline Thinning & 86 & 0.8 & 25 & 21 & 290 & 46 \\
\hline Clear-cutting & 121 & 1.0 & 38 & 25 & 386 & 386 \\
\hline
\end{tabular}


Work times were measured manually, with the use of the microcomputer PSION Workabout device (PSION TEKLOGIX Inc., Mississauga, Ontario, Canada) equipped with timing software especially designed for chronometry (PSION cumulative timing) (Suchomel et al. 2006; Sowa et al. 2007; Sowa and Szewczyk 2013). Simultaneously, the DOD LS 430W video camera (DODTech, ON, Canada) mounted in the operator's cabin recorded the same work cycles. The duration of different activities in the work cycle was recorded to the nearest second (PSION method) or $0.1 \mathrm{~s}$. (VIDEO method) and then classified according to the International Union of Forest Research Organisations (IUFRO) standards regarding forest work study nomenclature (Björheden 1991; IUFRO 1995; Szewczyk et al. 2014) (Table 2).

\section{Data analysis}

The recorded video footage was analysed using specialised computer software, Timer Pro Professional (Applied Computer Services, Inc., CO, USA), specially designed for chronometry (cumulative timing VIDEO). This software enables the investigator to stop the video footage at any point, rewind the recording frame by frame as many times as needed and select with great precision the exact moment when a particular operation occurred. The video footage was analysed by the same person who carried out the field research. This person had several months' experience in conducting time studies using PSION microcomputers and had also completed specialised training in operating the Timer Pro Professional software.

The average duration of work cycles was also determined from the data collected in the PSION microcomputer using the standard calculation method of snap-back timing. The snap-back timing method consisted of measuring the durations of certain operations separately (i.e. the timer is snapped back, or reset, at the end of each activity), determining their mean value and totalling the data obtained according to the arbitrary, theoretical structure of work time cycles (the total of

Table 2 Activities comprising the standard work cycle for a harvester operation

\begin{tabular}{lll}
\hline Work time categories & Activity code $^{\text {a }}$ & Activity description \\
\hline M W-main work time & 1 & Positioning \\
& 2 & Cutting \\
& 3 & $\begin{array}{l}\text { Felling/pulling a tree onto } \\
\text { a machine }\end{array}$ \\
& 4 & Delimbing and bucking \\
C W_complementary & 5 & Travel within a worksite \\
work time & &
\end{tabular}

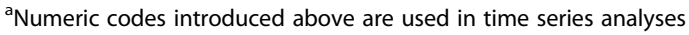
(Figs. 3, 4, 5 and 6) work times 1-5 in Table 2). Every main work cycle consisted of four activities: (1) positioning; (2) cutting time; (3) felling/pulling a tree onto a machine; and (4) delimbing and bucking (Nurminen et al. 2006) plus travel within a worksite (5). The start of the next cycle was indicated by another cutting operation.

The results obtained from the snap-back timing methods were compared with the cumulative timing PSION and cumulative timing VIDEO measurement methods. The mean duration of a work cycle was calculated based on the observed sequence of activities that occurred during the course of testing the measuring methods (cumulative timing PSION, cumulative timing VIDEO). The analyses were supplemented with the standard calculation method of snap-back timing. For this purpose, the database obtained in the VIDEO method was employed.

In the present research, it was assumed that the accuracy of the time study depended on: (1) the way in which work times were measured; and (2) the succession of work cycles. Due to the skewed distribution of the response variable, differences in the duration of work cycles and particular time categories, determined by the PSION (cumulative timing-CT PSION; snap-back timing-SB PSION) and the VIDEO (cumulative timing-CT VIDEO) methods, were compared using the non-parametric Mann-Whitney $U$ test. The duration of work cycles recorded by means of the applied calculation methods, CT PSION and CT VIDEO, was determined using the single-band Fourier analysis for time series, obtained upon encoding individual activities according to the scheme presented in Table 2. A sequence of activities was considered a time series. Names of the following operations, encoded as numbers, were the observed variables, while the succession of particular activities (work sequence) formed the ordering variable. In contrast to random sampling, time series are characterised by a non-incidental order of observations. For such data, a cyclicality of its occurrence can be determined, which was used in the study presented here. Having obtained a time series with the use of a moving average (equal weights), the single-band Fourier analysis was employed to detect a variable cyclical structure of the time series under investigation (Szewczyk et al. 2014). With regard to the snap-back timing PSION calculation method, the duration of a work cycle was determined for regular, five-activity cycles.

\section{Results}

Data were collected for 579 work cycles comprising a total number of 2327 events. The homogeneity of the research sample was examined using variance analysis of the time taken to travel between successive worksites (travel between successive work cycles as described in 
Table 2). With regard to tasks performed by the harvester, the above-mentioned activity is characterised by the greatest variability within the group of all operational work times (Szewczyk and Kulak 2013). This particular activity was selected for the analysis due to its high level of variability. No statistically significant difference was found in the mean travel time within a worksite; therefore, subsequent analyses were performed using the entire research sample.

\section{Duration of a work cycle}

In the thinning operation, the mean duration of a harvester work cycle, determined using the cumulative timing PSION method, was $48 \mathrm{~s}$ (Table 3), which was significantly shorter than the work cycle recorded using the cumulative timing VIDEO method $(Z=4.23 ; p<0.01)$. A statistically significant difference in work cycle duration between the measurement methods was also observed for the clear-cutting operation $(Z=2.09 ; p=0.04)$. In this case, the cycle time calculated using the cumulative VIDEO method was $11.2 \mathrm{~s}$ longer than that estimated by the cumulative PSION method. The variability in cycle duration was also greater than estimated by the cumulative VIDEO method. In contrast to both of the cumulative timing methods, longer work cycles were calculated for the clear-cutting operation using the snap-backing timing method (Fig. 1).

Underestimation of the duration of a harvester work cycle, measured by the cumulative timing PSION method in thinned stands, was due to underestimation of the duration of nearly all of the activity categories (Table 3). The greatest differences were recorded for the delimbing and bucking time (24\%). In the clear-cutting operation, the duration of delimbing and bucking activities was $5.3 \mathrm{~s}$ as determined by the cumulative timing PSION method in comparison with $26.2 \mathrm{~s}$ as determined by the cumulative VIDEO method. Large differences between timing methods were also observed for the duration of felling/pulling a tree onto a machine (cf. 4.1 and $19.3 \mathrm{~s}$ for CT VIDEO and CT PSION, respectively). Statistically significant differences were recorded for the travel time within a worksite, although the absolute difference was relatively small ( $2.6 \mathrm{~s})$.

\section{The number of activities within a work cycle}

A measure of changeability of work at the investigated trial plots was the variability in succession of the observed activities. The succession of activities was displayed by series of following work times, encoded as numbers (Tab. 2). This allowed the creation of two time series (one for thinning operations and one for clearcutting), whose observed variable was the sequence of activities (Figs. 2 and 3). A graphical analysis of the sequence of activities indicated that there were differences between thinning and clear-cutting operations. A significantly greater recurrence of work rhythm (visible as a sequence of the following numbers, operations) was recorded in thinning operations.

Trends observed in these studies were described with the use of periodograms of time series, the highest peaks of which indicated the length of a recurrent cycle of observations. The observed successive operations formed cycles, which were regarded as regular fluctuations of time series. In Figs. 4 and 5, the analysis of cyclicality of the examined time series was graphically presented: fragments of periodograms precisely indicated periods of work cycles (StatSoft Inc. 2009). In these figures, the values of spectral densities, noted in thinning and clearcut stands, show the frequency content in the stochastic process and allow for the identification of periodicity therein.

Table 3 Mean and median (in parentheses) duration of activities constituting a work cycle measured by either the VIDEO or the PSION method

\begin{tabular}{|c|c|c|c|c|c|c|}
\hline \multirow{3}{*}{$\begin{array}{l}\text { Activity number } \\
\text { and detail }\end{array}$} & \multicolumn{6}{|c|}{ Mean duration (s) } \\
\hline & \multicolumn{3}{|c|}{ Thinning operation } & \multicolumn{3}{|c|}{ Clear-cutting operation } \\
\hline & CT VIDEO & CT PSION & SB PSION & CT VIDEO & CT PSION & SB PSION \\
\hline 1. Positioning & $5.7(5)$ & $5.8(5)^{\mathrm{ns}}$ & $6.1(5)$ & $11.6(3)$ & $9.0(3)^{* *}$ & $4.0(3)$ \\
\hline 2. Cutting & $2.8(2)$ & $1.7(2)^{* *}$ & $2.2(2)$ & $4.2(24)$ & $3.9(6)^{\mathrm{ns}}$ & $4.4(3)$ \\
\hline $\begin{array}{l}\text { 3. Felling/pulling a } \\
\text { tree onto a machine }\end{array}$ & $6.6(5)$ & $5.3(5)^{\mathrm{ns}}$ & $5.6(5)$ & 4.1 (3) & $19.3(3)^{* *}$ & $29.9(27)$ \\
\hline $\begin{array}{l}\text { 4. Delimbing } \\
\text { and bucking }\end{array}$ & $27.7(26)$ & $22.8(24)^{* *}$ & $23.6(25)$ & $26.2(24)$ & $5.3(6)^{* *}$ & $10.8(6)$ \\
\hline $\begin{array}{l}\text { 5. Travel within } \\
\text { a worksite }\end{array}$ & $12.2(11)$ & $12.0(8)^{* *}$ & $14.1(8)$ & $6.2(7)$ & $3.6(5)^{* *}$ & $9.3(6)$ \\
\hline $\begin{array}{l}\text { Total duration of } \\
\text { a work cycle }\end{array}$ & 55.0 & 47.6 & 51.6 & 52.3 & 41.1 & 58.4 \\
\hline
\end{tabular}

The statistical significance of differences between the median values for the two cumulative timing methods is indicated with standard symbols. ns not significant 


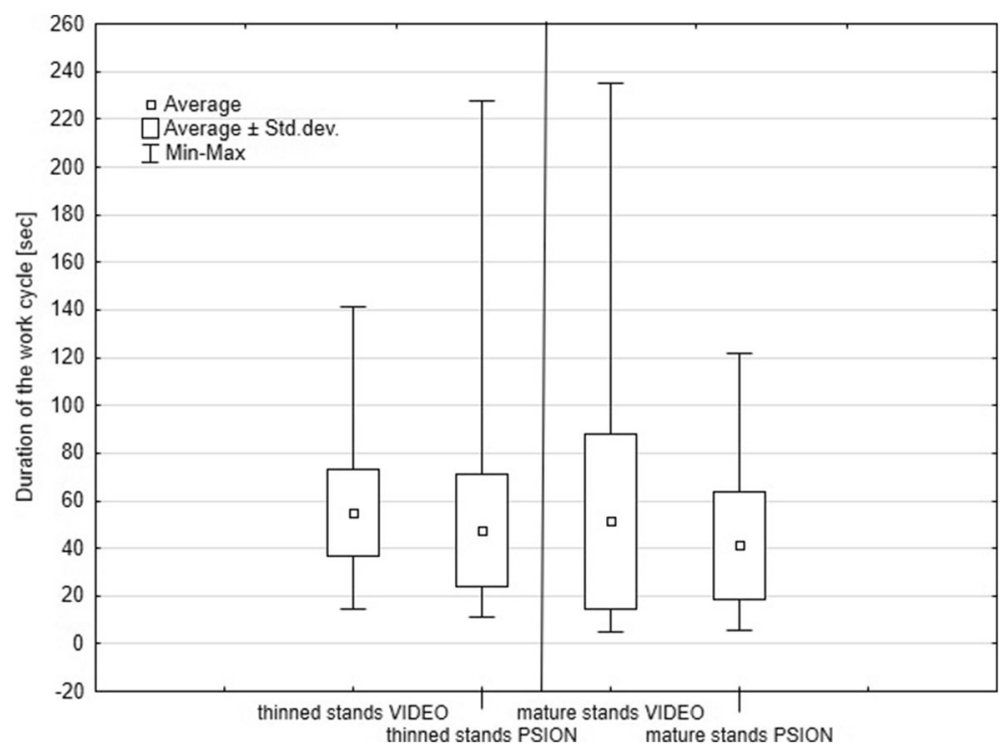

Fig. 1 Descriptive statistics of the duration of a harvester work cycle determined by means of the cumulative timing PSION and the cumulative timing VIDEO methods - thinned and mature stands

Harvester operations in thinned stands were performed in stable, five-activity cycles, which was marked by the highest peak in the periodogram in Fig. 4. With regard to clear-cut stands, overlapping cycles of various lengths were recorded, while the total variability was described by two sequences: a considerably shorter one with five activities and a longer one containing several dozen activities (Fig. 5).

In the thinning operations, the trees designated for felling were evenly distributed throughout the entire stand, and the number of assortments produced was smaller than obtained from clear-cut stands. Consequently, in thinned stands, the harvester operated within stable work cycles in terms of the number of activities per single work cycle, and the difference in work times between the standard calculation method, snap-back timing PSION and the two cumulative timing methods was much smaller than that in the clearcutting operations. The duration of work cycles in a thinning operation, determined for the arbitrarily established work cycles, was underestimated by $6 \%$ when using the snap-back timing relative to the

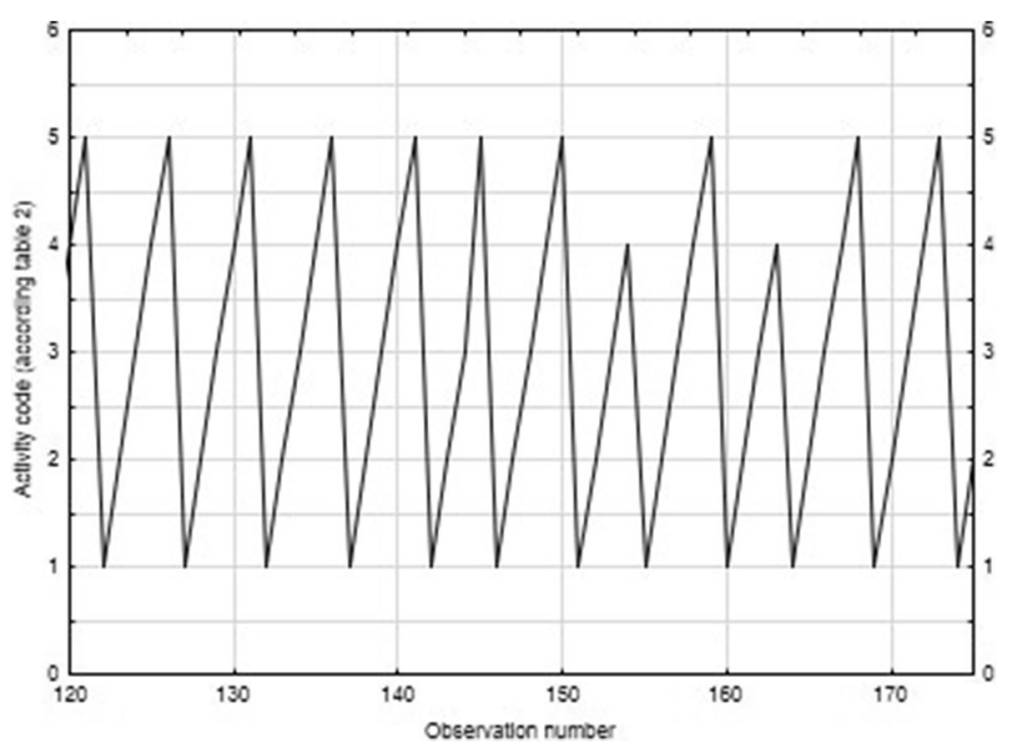

Fig. 2 Fragment of a time series of operations performed by a harvester in thinned stands 


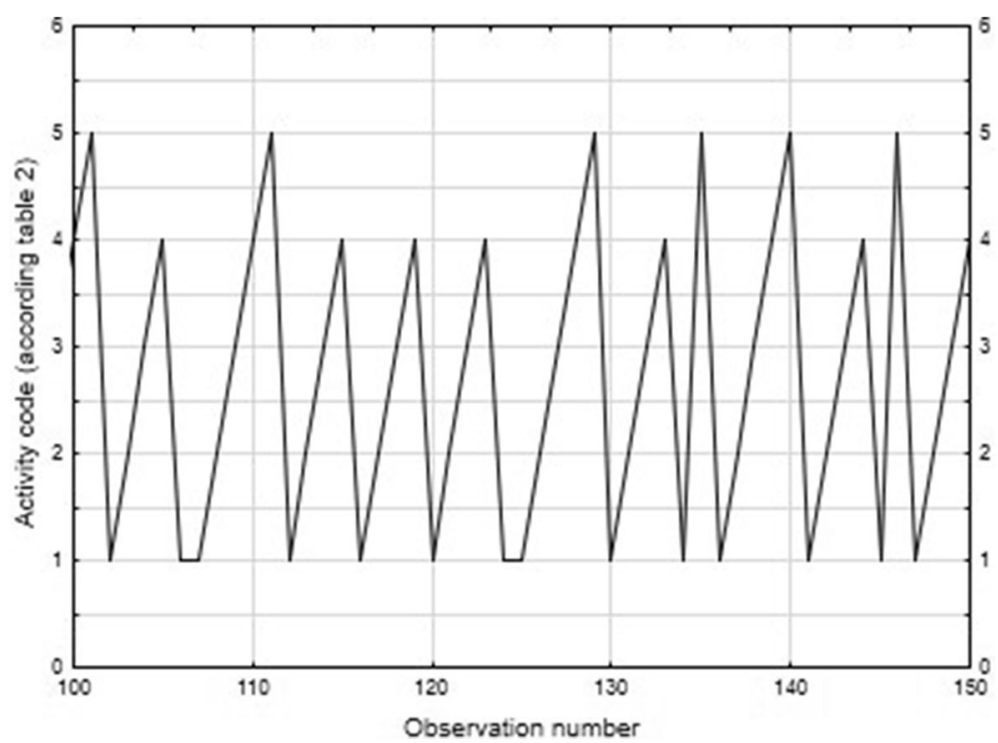

Fig. 3 Fragment of a time series of operations performed by a harvester in mature stands

cumulative video timing, while in the clear-cutting operation, the difference was approximately 12\% (Fig. 6). In clear-cut stands, due to greater dimensions of trees, it was sometimes necessary to repeat a particular operation more than once within a work cycle, e.g. operations of delimbing and bucking were performed several times while processing a single tree stem.

\section{Discussion}

The tasks that are currently set up as the objective of a work study do not differ substantially from those formulated by F.W. Taylor over 100 years ago: "A piecerate system being a step toward partial solution of the labour problem" (Koŝir et al. 2015). The weight of research has shifted slightly towards the optimisation of production systems, and traditional (manual) measurement methods are partly replaced by automated bases. The StanForD control and measurement standard (Dvorák et al. 2011), applied in harvesters, enables the acquisition of a huge database. The problems of using such measurements consist in the lack of verification of certain categories of time and in treating a work cycle as a whole (Purfürst and Erler 2011). For this reason,

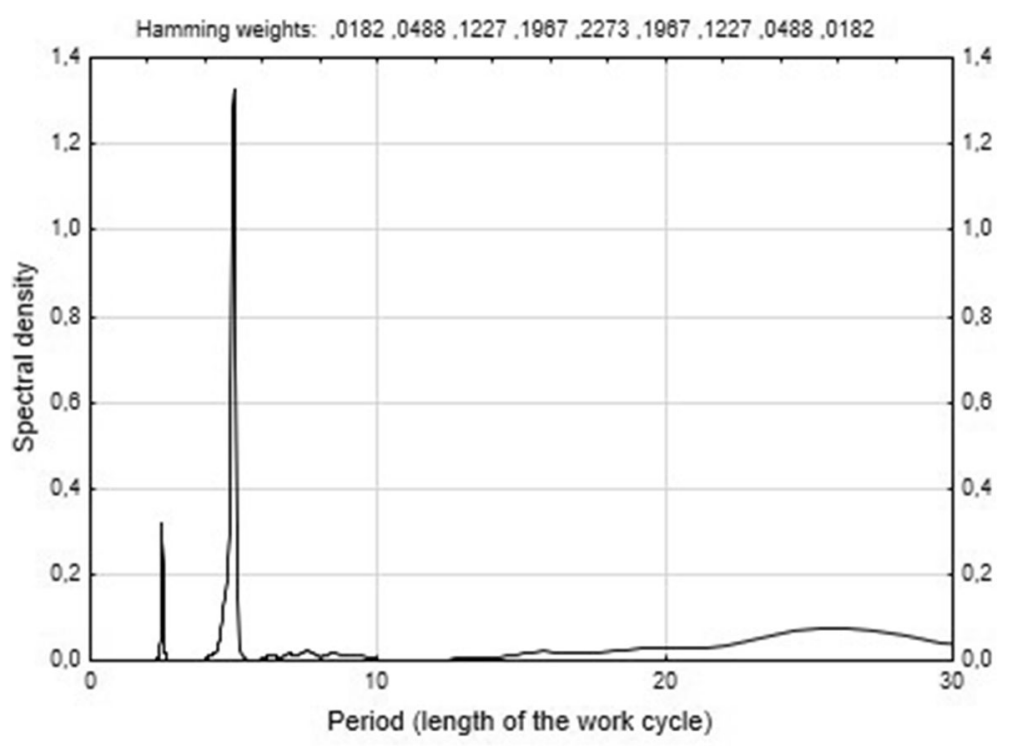

Fig. 4 Fragment of a periodogram of a harvester operating in thinned stands 


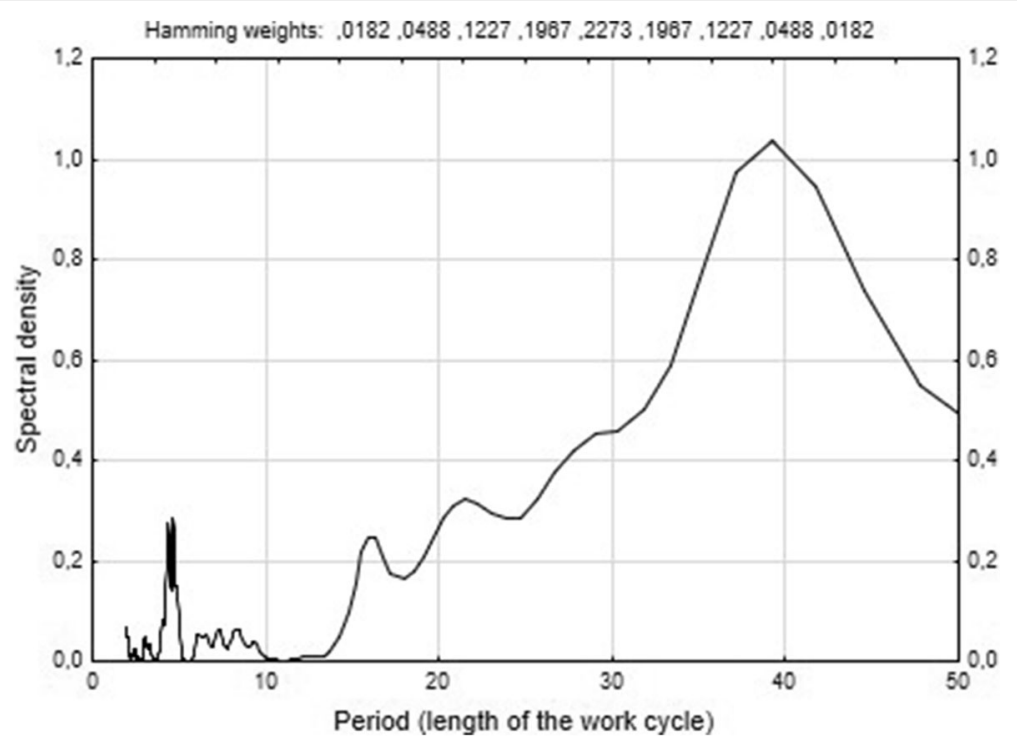

Fig. 5 Fragment of a periodogram of a harvester operating in mature stands

microcomputers are still used in manual measurements with the manual feeding of time points. The effect of the "human factor" is marked very clearly in the form of errors due to the lack of skill of time recorders and their fatigue, especially in long-term measurements (Nurminen et al. 2006). In the present study, thanks to determination of the reference level (video material), an additional factor was identified which consists of recording short-term activities with difficult-to-establish border points.

The primary purpose of determining the duration of work is to determine the time- and cost-effectiveness of the applied technologies; hence, a time study is usually performed as a continuous study with continuous observation according to the current time (Mederski 2013). This research method is used not only in performance tests but also in analyses of machine operator techniques (Ovaskainen et al. 2004). According to the IUFRO classification (1995), the most useful methods are cumulative timing (Szewczyk 2011b; Nurminen et al. 2006; Dvořák and Walczyk 2013), which yields a cumulative time of observed operations, and a check study, which is a preliminary work variability test aimed to determine the size of a trial sample. Time studies are often the starting point for determining the structure of working time. In the latter case, the appropriate method of measurement would be snap-back timing, which involves separate measurements of elements of work (Bergstrand 1987; Jourgholami et al. 2013; Yoshida and Sakai 2015).

The method of working time measurement with regard to timber harvesting was the object of research in terms of technique of execution (Miyata et al. 1981;

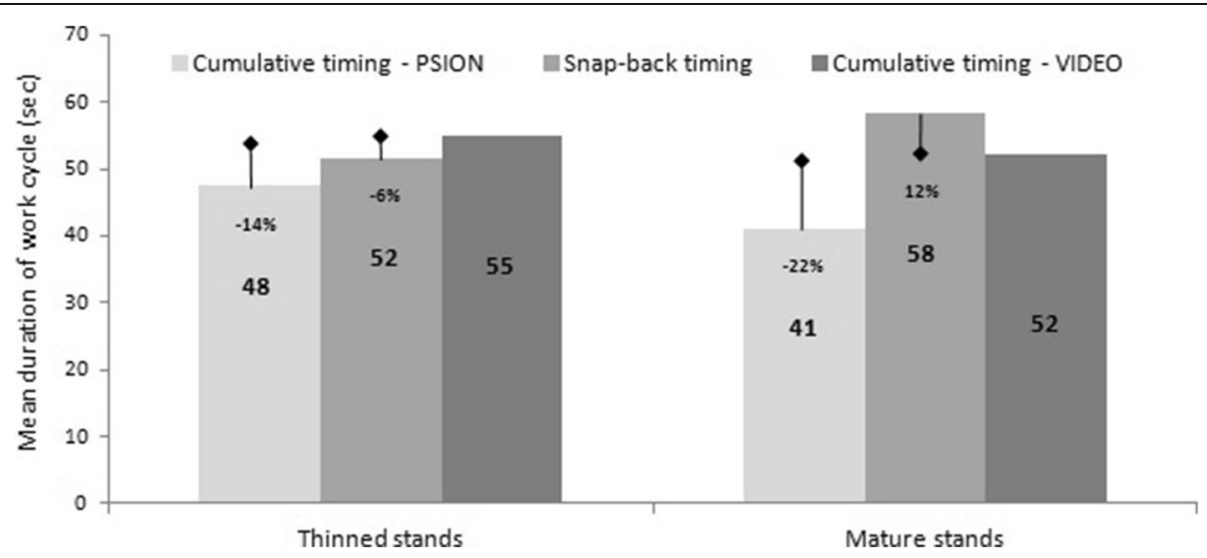

Fig. 6 Percentage value of the measurement error and the mean duration of a work cycle in the investigated calculation methods, in relation to the cumulative timing VIDEO method 
Samset 1990) and accuracy in the context of work performance by persons with different levels of training and fatigue (Nuutinen et al. 2007; Spinelli et al. 2013). The necessity to standardise the research methods used in analyses of work with regard to the formulation of work/ research objectives, designing experiments, applying appropriate statistical models, adopting appropriate measurement models and elaborating the results has been underlined several times in recent years (Magagnotti et al. 2013). It seems that in the chronometric studies, two more measurement factors require being specified as they have a fundamental impact on the results: the timemeasuring technique and the adoption of the proper structure, or "division" of the duration of a given technological operation.

When designing experiments concerning working time, usually two levels of accuracy (seconds per observed operation) are determined arbitrarily: measurement accuracy and the minimum duration of a single operation (Szewczyk 2011a). Samset (1990) and Kanawaty (1992) pointed to the smaller accuracy of measurement of work cycles consisting of categories with significantly different variability and percentage. Hence, for example, in measurements of a chain saw operator's work, operations with a duration of less than $0.1 \mathrm{~min}$ are usually not distinguished while delimbing and bucking operations are usually combined (Sowa et al. 2009; Szewczyk 2009). In analyses of the operation of multi-purpose machines, due to the high variability of operations, the accuracy of measurements is much higher. The time measurement applied in the present study, performed with the accuracy of $1 \mathrm{~s}$, corresponds to the generally applied standards, especially when the work time databases are being constructed during analyses of the video material. Although Pukkila (1969) performed measurements with the accuracy of $2 \mathrm{~s}$, his chronometric measurements concerned less variable work stations in forestry. In their research on machine performance in the CTL harvesting system, Nurminen et al. (2006) determined the duration of individual operations with the use of the counter in a camcorder, reaching a very high accuracy of $1 / 24 \mathrm{~s}$. The minimum duration of a single operation adopted in further analyses in the present study should take into account its observed variability and the total length of the work cycle. The accuracy level of $1 \mathrm{~s}$, adopted in the present study, is higher than in previous research by Szewczyk (2011a), but it corresponds better to the accuracy of Timer Pro Professional software used for video footage analyses (up to 1/1000 s).

The accuracy of timing measurements is usually linked to the degree of work variability. Seemingly, the problem only comes down to determining the length of a work cycle and dividing it into components. The degree of accuracy of the work cycle division adopted in our study was consistent with the standard classifications seen in other studies (Picchio et al. 2012). The structure of the duration of individual operations observed in work cycles was similar to those reported in other studies, and the differences were due to different stand conditions (Nurminen et al. 2006). The stands analysed in our study were characterised by larger tree diameter, and therefore, the duration of wood-processing operations was higher ( $42 \%$ in thinning stands, $52 \%$ in clear-cut stands). A similar situation occurred in the case of travel time between successive work stations. The most likely factor was the impact of the lack of access to the stands via the skid trails.

Time studies consist in measuring repetitive work cycles; therefore, determining their structure is a key issue when planning measurements. Magagnotti and Spinelli (2012) only specify that the structure of a work cycle should accurately describe the work process. The degree of detail of the work cycle division should reflect the degree of complexity of the work. In this respect, the present study is a development of research on work variability and the appropriate selection of measuring tools (Szewczyk 2011a, 2011b, 2014a, 2014b), thus contributing a new element to the issue of work analysis. The present analyses have determined a new factor shaping the accuracy of chronometric measurements, namely the real structure and length of a work cycle that is observable in the field. It is these factors that should, by definition, be taken into account in the design of measurements. According to the current general assumptions, the structure of harvester work cycles is considered to be stable, which is a great simplification. Due to the variability of harvesting conditions, the rhythm of work in different areas may vary, and this should be reflected by the method of taking measurements. In practice, it is difficult to apply detailed methodological procedures on single felling sites (the time series method presented in our study) so as to describe the variability and determine the correct duration of work cycles. In view of the above, simplified indices of the measurement error level could be used, as proposed in our study for operations characterised by lower (thinning operations) and higher (clear-cut operations) work variability.

\section{Conclusions}

The accuracy of work time measurements employing chronometric methods is of particular importance for investigation of highly variable technological operations, with short-lasting activities, which is typical of harvester operation. Microcomputers, employed in such studies for more than a decade, may produce errors resulting from the inertia of measurements, due to the manual input of terminal points of the operations under analysis 
and to misjudging the number of operations constituting a work cycle.

While conducting regular time studies, the existence of work cycles with a stabilised succession of work times is assumed. Particularly, with regard to work sites characterised by a great variability of work, the factual structure of work cycles should be determined, which would be easier if the method of work time series, discussed in this paper, was employed. The primary results indicated that the snap-back timing method is slightly more accurate than the cumulative timing method, in reference to both stable work cycles and more variable work time structure.

For time studies covering harvester operations where the duration of particular activities is measured manually, the snap-back timing method should be recommended, since it is based on measuring the time of every operation separately, determining a mean value of their duration and totalling the data obtained according to the arbitrary, theoretical structure of work cycles.

\section{Acknowledgements}

This work was supported by the Ministry of Science and Higher Education of Poland under Grant No. DS ZULiD/3412/2015.

\begin{abstract}
Authors' contributions
GS made a substantial contribution to the conception and design, acquisition of data, analysis and interpretation of data and has been involved in drafting the manuscript and revising it critically for important intellectual content. He has participated sufficiently in the work to take public responsibility for appropriate portions of the content and agreed to be accountable for all aspects of the work in ensuring that questions related to the accuracy or integrity of any part of the work are appropriately investigated and resolved (70\%). JMS made a substantial contribution to the conception and design and has been involved in drafting the manuscript or revising it critically for important intellectual content. He has participated sufficiently in the work to take public responsibility for appropriate portions of the content and agreed to be accountable for all aspects of the work in ensuring that questions related to the accuracy or integrity of any part of the work are appropriately investigated and resolved (30\%). Both authors read and approved the final manuscript.
\end{abstract}

\section{Competing interests}

The authors declare that they have no competing interests.

\section{Publisher's Note}

Springer Nature remains neutral with regard to jurisdictional claims in published maps and institutional affiliations.

Received: 7 April 2016 Accepted: 16 November 2017

Published online: 05 December 2017

\section{References}

Bergstrand, KG (1987). Planning and analysis of time studies on forest technology. Kista: The Forest Operations Institute of Sweden.

Björheden, R. (1991). Basic time concepts for international comparison of time study reports. Journal of Forest Engineering, 2, 33-39.

Borz, SA, Ignea, G, Popa, B, Spârchez, G, lordache, E. (2015). Estimating time consumption and productivity of roundwood skidding in group shelterwood system - a case study in a broadleaved mixed stand located in reduced accessibility conditions. Croatian Journal of Forest Engineering, 1, 137-146.

Dvorák, J, Bystrický, R, Hošková, P, Hrib, M, Jarkovská, M, Kováč, J, Krilek, J, Natov, P, Natovová, L (2011). The use of harvester technology in production forests. Kostelec nad Černými lesy: Folia Forestalia Bohemica.
Dvořák, J, \& Walczyk, J. (2013). Wydajność pozyskania drewna przy pomocy harwesterów i pilarki spalinowej [Productivity of timber harvest with the use of a harvester and a chainsaw]. Sylwan, 157, 171-176.

Eliasson, L, Hofsten, H, Johanesson, T, Spinelli, R, Thierfelder, T. (2015). Effects of sieve size on chipper productivity, fuel consumption and chip size distribution for open drum chippers. Croatian Journal of Forest Engineering, $1,11-18$.

IUFRO (1995). WP 3.04.02. Forest work study nomenclature, Test edition valid 19952000. Garpenberg: Department of Operational Efficiency, Swedish University of Agriculture Science.

Jourgholami, M, Majnounian, B, Zargham, N. (2013). Performance, capability and costs motor-manual tree felling in Hyrcanian hardwood forest. Croatian Journal of Forest Engineering, 2, 283-293.

Kanawaty, G (1992). Introduction to work study. Geneva: International Labour Office.

Kangas, J, Kangas, A, Leskinen, P, Pykäläinen, J. (2002). MCDM methods in strategic planning of forestry on state-owned lands in Finland: applications and experiences. Journal of Multi-Criteria Decision Analysis, 5, 257-271.

Koŝir, B, Magagnotti, N, Spinelli, R. (2015). The role of work studies in forest engineering: status and perspectives. International Journal of Forest Engineering, 3, 160-170. https://doi.org/10.1080/14942119.2015.1111043.

Magagnotti, N, Kanzian, C, Schulmeyer, F, Spinelli, R. (2013). A new guide for work studies in forestry. International Journal of Forest Engineering, 3, 249-253. https://doi.org/10.1080/14942119.2013.856613.

Magagnotti, N, \& Spinelli, R (2012). Good practice guidelines for biomass production studies. Sesto Fiorentino: CNR Ivalsa.

Mederski, PS (2013). Możliwości zastosowania harwestera do pozyskiwania drewna w mieszanych drzewostanach brzozowo-sosnowych [Possibility of engaging a harvester in timber harvesting in mixed birch-and-pine stands]. Poznań: Publishing House of the Poznań University of Life Science.

Miyata, ES, Steinhilb, HM, Winsauer, SA (1981). Using work sampling to analyze logging operations. St Paul, MN, USA: North Central Forest Experiment Station, Forest Service - U.S. Department of Agriculture.

Nurminen, T, Korpunen, H, Uusitalo, J. (2006). Time consumption analysis of the mechanized cut-to-length harvesting system. Silva Fennica, 2, 335-363.

Nuutinen, Y, Väätäinen, K, Heinonen, J, Asikainen, A, Röser, D. (2007). The accuracy of manually recorded time study data for harvester operation shown via simulator screen. Silva Fennica, 1, 63-72.

Ovaskainen, H, Uusitalo, J, Väätäinen, K. (2004). Characteristics and significante of a harvester operator's working technique in thinnings. International Journal of Forest Engineering, 2, 67-77.

Palmroth, L (2011). Performance monitoring and operator assistance systems in mobile machines. Tampere, Finland: Tampere University of Technology.

Picchio, R, Sirna, A, Sperandio, G, Spina, R, Verani, S. (2012). Mechanized harvesting of eucalypt coppice for biomass production using high mechanization level. Croatian Journal of Forest Engineering, 1, 15-24.

Pukkila, A (1969). Työntutkimus [Work-study]. Helsinki: Kustannusosakeyhtiö Otavan kirjapaino.

Purfürst, FT, \& Erler, J. (2011). The human influence on productivity in harvester operations. International Journal of Forest Engineering, 2, 15-22.

Sajkiewicz, A (1981). Ekonomika pracy [Labour economics]. Warszawa: Państwowe Wydawnictwo Ekonomiczne.

Samset, I (1990). Some observations on time and performance studies in forestry. Fana: Norsk Institutt for Skogforskning.

Skoupý, A (2011). Sophisticated model for nature-friendly timber haulage evaluation. In RJ Starzyk (Ed.), Technology and ergonomics in the service of modern forestry, (pp. 241-251). Kraków: Publishing House of the University of Agriculture in Kraków.

Smidt, MF, \& McDaniel, J. (2012). Utilization, cost, and landowner return from whole-tree chipping young loblolly pine thinnings. Croatian Journal of Forest Engineering, 2, 211-223.

Sowa, JM, Kulak, D, Leszczyński, K, Szewczyk, G (2007). Związki struktury dnia roboczego z fizjologiczną gotowością do pracy na stanowisku operatora pilarki spalinowej [Relations between the work day structure and the physiological readiness for work at the worksite of a petrol chainsaw operator]. In D Giefing (Ed.), XII Konferencja Ergonomiczna, (p. 28). Poznań AR Poznań. Poznań - Puszczykowo: PTErg Oddz.

Sowa, JM, \& Szewczyk, G. (2013). Time consumption of skidding in mature stands performed by winches powered by farm traktor. Croatian Journal of Forest Engineering, 2, 255-265.

Sowa, JM, Szewczyk, G, Stańczykiewicz, A, Grzebieniowski, W. (2009). Pracochłonność pozyskiwania drewna w drzewostanach ze śniegołomami 
[Labour consumption during timber harvesting in snowbreak stands]. Leśne Prace Badawcze, 4, 429-434.

Spinelli, R, Laina-Relańo, R, Magagnotti, N, Tolosana, E. (2013). Determining observer and method effects on the accuracy of elemental time studies in forest operations. Baltic Forestry, 2, 301-306.

Stampfer, K, \& Lexer, MJ (2003). Multicriteria evaluation of thinning operations on steep terrain. In U Arzberger, M Grimoldi (Eds.), New trends in wood harvesting with cable systems for sustainable forest management in the mountains, (pp. 1-9). Ossiach: University of Natural Resources and Life Sciences Vienna.

StatSoft Inc. (2009). STATISTICA (data analysis software system), version 9.0. http:// documentation.statsoft.com/STATISTICAHelp.aspx?path=common/ AboutSTATISTICA/ElectronicManuallndex. Accessed 21 Nov 2017.

Suchomel, J, Slančik, M, Fógel, S (2006). Návrh systému pre modernizáciu vedenia Ihe, evidenciu zásob a operativne riadenie odvozu a odbytu surového dreva [Project of modernisation system for inventorying and managing the process of timber harvesting and hauling]. In A Skoupy (Ed.), Perspektivy vývoja t'ažbovo-dopravného procesu a využitia biomasy v lesnom hospodárstve [Perspectives on development of timber harvesting process and utilisation of biomass in forestry], (pp. 219-225). Zvolen: Technicka Univerzita vo Zvolene, Lesnicka Fakulta.

Szewczyk, G. (2009). Możliwości wykorzystania wskaźników intensywności trzebieży w kategoryzacji warunków pracy dla wybranych technologii pozyskiwania drewna na ręczno-maszynowym poziomie zmechanizowania [Possibilities of using indices of intensity of thinning treatments in categorisation of work conditions for selected motor-manual technologies of timber harvesting]. Acta Agraria et Silvestria, Series Silvestris, XLVII, 27-45.

Szewczyk, G (2011a). Variability of the harvester operation time in thinning and windblow areas. In RJ Starzyk (Ed.), Technology and ergonomics in the service of modern forestry, (pp. 183-196). Kraków: Publishing House of the University of Agriculture in Kraków.

Szewczyk, G. (2011b). Czasochłonność zrywki drewna wyciągarkami zagregowanymi z pilarkami spalinowymi w drzewostanach trzebieżowych [Time consumption of skidding operations using winches aggregated with chainsaws in thinned stands]. Sylwan, 6, 401-412.

Szewczyk, G. (2014a). Obserwacje migawkowe w pomiarach pracy przy pozyskiwaniu i zrywce drewna [Snapshot observations in measuring work time at timber harvesting and skidding]. Sylwan, 11, 803-810.

Szewczyk, G. (2014b). Model strukturalny dynamiki zmienności pracy na wybranych stanowiskach roboczych w pozyskiwaniu i zrywce drewna [Structural model of dynamics of work variability at selected worksites in timber harvesting and skidding]. Zeszyty Naukowe Uniwersytetu Rolniczego im. Hugona Kołłątaja w Krakowie nr 522. Rozprawy, zeszyt 399. Kraków: Publishing House of the University of Agriculture in Kraków.

Szewczyk, G, \& Kulak, D. (2013). Kosztochłonność pozyskania drewna harwesterem w drzewostanach przebudowywanych z zastosowaniem cięć częściowych. [Cost effectiveness of timber harvest with a harvester in the stands rebuilt under the shelterwood system]. Sylwan, 4, 243-252.

Szewczyk, G, Sowa, JM, Grzebieniowski, W, Kormanek, M, Kulak, D, Stańczykiewicz, A. (2014). Sequencing of harvester work during standard cuttings and in areas with windbreaks. Silva Fennica, 48, 1-16. 10.14214/sf.1159.

Szewczyk, G, \& Stańczykiewicz, A. (2012). Model szacowania pracochłonności pozyskiwania drewna w drzewostanach ze śniegołomami [Estimation model for labour consumption of timber harvesting in stands with snowbreaks]. Leśne Prace Badawcze, 2, 167-173.

Walczyk, J, Kormanek, M, Walczykova, M (2009). Video-computer technique in determining of the skidding tractors soil-wheel contact area. In A Skoupy (Ed.), Krajina, les a lesni hospodárstvi [Landscape, forests and forestry], (pp. 292299). Prague: Česká Zemědělská Univerzita v Praze.

Yoshida, M, \& Sakai, H. (2015). Winch harvesting on flat and steep terrain areas and improvement of its methodology. Croatian Journal of Forest Engineering, $1,55-61$.

\section{Submit your manuscript to a SpringerOpen ${ }^{\circ}$ journal and benefit from:}

- Convenient online submission

- Rigorous peer review

- Open access: articles freely available online

- High visibility within the field

- Retaining the copyright to your article

Submit your next manuscript at $\gg$ springeropen.com 